\title{
Risk Premium and Its Effect on Bank's Non-Performing Loans
}

\author{
Hafiz Waqas Karman, Shameer Malik, Hamas Butt, M. Hamza, Umair Afzal, \\ Shahzaib Maqbool \\ University of Central Punjab, Faisalabad, Pakistan
}

\begin{abstract}
The present outcomes of risk premium have started the discussion over the Bank's nonperforming loans and its determinants. Banking sector is taking active part in different fields of life such as financing, business transactions and loan provisions. Therefore, it is very important for the management to make good decisions relating to the non-performing loans of the bank. In the current study, we have conducted an analysis in order to examine the risk premium and its effect on bank's non-performing loans in 8 western countries of the world based on GDP over a period from 1998 to 2010. A conceptual model has been developed for this purpose and panel data analysis has been performed. Key finding have been explained for the financial expert to make the future decisions. Our result shows that there is significant relationship between risk premium and bank's non-performing loans.
\end{abstract}

Key words: Risk premium, Bank non-performing loans, GDP growth rate

\section{INTRODUCTION}

The banks are those types of organizations that focus on dealing with financial transactions like investment, loans and deposits. The return in excess of the hazard-loose rate of return that an investment is expected to yield. An asset's hazard premium is a form of reimbursement for traders who tolerate the greater risk compared to that of a threat-free asset in a given investment. A sum up borrowed cash upon which the debtor has no longer made his or her scheduled bills for as a minimum ninety days. A non-performing mortgage is either in default or near being in default. Once a mortgage is non-performing, the percentages that it will likely be repaid in complete are considered to be appreciably decreasing. If the debtor begins making payments once more on a non-performing loan, it turns into a performing mortgage, even supposing the debtor has now not caught up on all of the overlooked bills.

The core process of the present study is to examine the optimum relationship in between risk premium and its effect in non-performing loans. In assessment, prudential financial institution law seeks to limit the frequency and value of financial institution failures and to defend the financial gadget as an entire by restricting the frequency and value of systemic crises (e.g., Richet, 2005). Those differing objectives are at the centre of a standing debate over mortgage loss accounting as reflected in current high profile proposals via the monetary balance forum (2009) and U.S. Treasury (2009). Policy makers argue the incurred loss version underlying present day mortgage loss accounting reinforces seasoned-cyclical effects of financial institution capital regulation, and need to consequently be changed to permit financial institution managers more discretion to comprise aheadlooking judgments into loan loss provisions. 
While considering the risk premium, it is quite significant to deal with major determinants of nonperforming loans and its ultimate impact on the financial performance on the various Banks' currently working in western countries.

\section{LITERATURE REVIEW}

Since form the 1998, the number of studies has been conducted to define the major determinants of risk premium effects on non-performing bank loans. In the microeconomic structure, literature point of view two important determinants are risk premium and non-performing loans. (Barseghyan, 2010) states the fact that the delay in the authority's bailout of the financial sector played a key role in Japan's slowdown for the duration of the 1990s and early 2000s. During this duration, the growth rate of per capita GDP of Japan was $1.2 \%$ per year, and in 1980 it was 3.5\% per year. This argument is articulated in a general equilibrium model wherein the government affords deposit coverage to the monetary sector. The lifestyles of non-appearing loans, combined with a postpone inside the bailout, ends in a continual decline in economic pastime. Constant with Japan's experience, the decline in output is brought on no longer best through a fall in investment, however also by a decline in hard work and general aspect productiveness.

(Bushman \& Williams, 2012) states the fact that examining banks throughout 27 countries, we estimate measures of the ahead-searching orientation contemplated in discretionary mortgage provisioning practices within a country. In evaluation, forward-looking provisioning reflecting timely popularity of expected destiny mortgage losses is associated with more advantageous chance-taking subject. We version two factors of discretionary ahead-looking mortgage loss provisioning via banks round the world. Provisioning tied to modern-day duration income reduces financial institution area. Provisioning tied to modern-day duration earnings will increase discovered danger-shifting behaviour in banks. Provisioning tied to destiny adjustments in non-appearing loans will increase the area of banks. Provisioning tied to future changes in non-performing loans decreases observed chance-shifting conduct in banks.

(Ioannidou \& Penas, 2010) states the fact that analyses the effect of deposit coverage on the risktaking conduct of banks in the context of a quasi-natural experiment the usage of distinctive credit registry data. The usage of the case of a rising economic system, Bolivia, which introduced a deposit coverage machine for the duration of the pattern duration, we evaluate the danger-taking conduct of banks earlier than and after the creation of this system. We discover that in the submit-deposit coverage duration, banks are more likely to initiate riskier loans. Those loans convey better interest fees and are associated with worse ex-put up performance. Banks do now not appear to atone for the more danger via growing collateral requirements or decreasing loan maturities. We additionally locate proof that the growth in danger-taking is because of the lower in marketplace subject from massive depositors. Sooner or later, differences between large and small banks diminished inside the put updeposit insurance length.

(Chateau \& $\mathrm{Wu}, 2007$ ) states the fact that this study makes two contributions: to charge analytically placed choice and extension top rate embedded in a borrower-extendible commitment, and to compute the 'truthful' capital price that corresponds to the commitment 'authentic' credit risk. The procedure replaces the BIS accounting-primarily based concepts of credit score-conversion thing, predominant-threat factor, and preliminary term to adulthood of irrevocable commitments with the market-based ideas of workout-cum-takedown percentage and placed cost implicit within the borrower-extendible dedication, respectively. Finally, the approach is developed one step in addition to account for the debtors' chance scores by using public credit groups; this results in a two-dimensional hazard-weighting gadget that applies to all dedication types.

(Cook, Schellhorn, \& Spellman, 2003) states the fact that the announcement of a bank mortgage by a borrowing company has been shown to have a high-quality impact in the marketplace cost of the borrower's claims. This is consistent with a lender's implied endorsement of the borrower-an endorsement that has cost to the borrower. In this paper, we inspect whether the lender is capable of 
extract a premium loan charge or certification premium in return. We discover empirical evidence that within the absence of collateral legit creditors are able to exact a certification top class.

(Stanhouse \& Stock, 2004) states the fact that numerous studies have analysed how a financial institution's intermediation margin varies with recognize to such elements as credit nice, funding danger, financial institution capital, deposit insurance and other elements. These studies ignore the capacity that loans tend to prepay if interest costs decline and deposits tend to be withdrawn if interest prices upward push. Taking this very fundamental truth under consideration, we derive optimal mortgage charges and deposit charges when the bank is challenge to loan prepayments and deposit withdrawals. Amongst different things, we find that greater volatility of interest prices has a tendency to boom the margin. The strength of the correlation between the level of interest charges and the propensity to prepay loans also performs an interesting role.

(Hassan \& Sackley, 1994) states the fact that offers in addition empirical proof of capital marketplace reactions to the increase and riskiness of bank off-balance sheet loan dedication activities. Preceding studies have unnoticed the effect of law on the dimension of financial institution danger. On this study Ronn-Verma and Gorton-Santomero choice pricing models are employed to calculate implied asset hazard from financial institution fairness and subordinated debt. This approach contains the nonlinearity of contingent claims valuation models, deposit insurance and regulatory closure guidelines. This studies reviews sturdy evidence that loan commitments reduce bank threat. Decreases in equity danger, subordinated debt default hazard and implied asset risk on account of increases in mortgage commitments sports implies that mortgage commitments can also contribute to the overall diversification of financial institution portfolio chance. It can be irrelevant to include mortgage commitments in a threat-based totally capital calculation.

(Dietsch \& Petey, 2015) states the fact that analyses the credit danger of housing loans with a selected consciousness on mechanisms that can assist disentangling the economic constraints of lowearnings debtors: public assist and get entry to adjustable-price loans. The use of a massive database of French housing loans masking the years 2000-2010, we display the subsequent: supplying loans with monetary assistance helps financially restrained borrowers to take in earnings shocks, adjustablecharge loans are riskier on average, and the aggregate of public aid and adjustable charges can cause a concentration of threat within the lender's portfolio. The chance dimension technique used in this paper extends the only-element monetary capital model underlying the Basel 2 regulatory credit score-hazard formulas. This portfolio technique results in the credit chance of housing loans being handled as a portfolio control issue for the lender.

(Jorge, 2009) states the fact that we strengthen a reason behind the delay inside the response of the extent of financial institution loans to innovations in economic coverage. Capital necessities may successfully tie the evolution of financial institution credit to the evolution of bank fairness. By means of uncovering a new mechanism by which shifts in interest costs have an effect on the profitability of the banking region, and in flip its equity, we discover that the resulting moves in the amount of mixture loans are steady with the regularities observed within the records.

(Giulioni, 2015) states the fact that we examine a financial institution loan portfolio choice by way of a backside up computational technique. Low tiers of the policy interest price lead banks to choose high danger debtors. A reduction of $r$ increases the volatility of the bank coins influx. The loan portfolio risk increases soon after an boom of real reduction of the lending time horizon increases coins inflow volatility clustering. Using a computational technique that absolutely bills for borrowers' heterogeneity, we display how the variety of financial institution clients modifications and the way this modification influences the financial institutions cash influx, making it extra risky. The paper additionally sheds mild on how the composition of the mortgage portfolio is affected by a growth in the coverage interest charge whilst its miles saved at low tiers. More secure borrowers exit the mortgage portfolio first, inflicting a sluggish boom inside the mortgage portfolio chance.

(Centeno \& Mello, 1999) states the fact that his paper estimates integration vectors of the time collection of cash marketplace hobby prices and financial institution lending rates. The study includes 
six member international locations of the ecu Union and covers a period of 10 years, from 1985 to 1994. All through this era, widespread steps had been taken that intensified monetary integration within the European, together with the free float of capital, a system of solid trade-rate parities and the implementation of a single market for banking services. We finish that the home cash markets are closely related, however the home banking markets are segmented. Preliminary research of international variations inside the capital shape of firms, on the only hand, and of home business cycle situations, then again, do no longer seem to give an explanation for variations in financial institution spreads throughout international locations. The results factor to different guidelines, possibly to neighbourhood market strength and to differences within the position of lender tracking.

(Cerqueiro, Degryse, \& Ongena, 2011) states the fact that loan rates for seemingly same borrowers frequently show off enormous dispersion. This paper investigates the determinants of the dispersion in interest costs on loans granted by way of banks to small and medium sized corporations. We partner this dispersion with the loan officers' use of "Discretion" within the mortgage price placing process. We find that "Discretion" is maximum important if: loans are small and unsecured; firms are small and opaque; the firm operates in a huge and tremendously concentrated banking marketplace; and the company is distantly located from the lender. Regular with the proliferation of informationtechnologies in the banking enterprise, we discover a reducing position for "Discretion" over the years within the provision of small credit to opaque corporations. Even as broadly used inside the pricing of loans, "Discretion" plays handiest a minor role in the selections to supply loans.

(Lehar, 2005) states the fact that loan rates for seemingly identical borrowers often exhibit substantial dispersion. This paper investigates the determinants of the dispersion in interest rates on loans granted by banks to small and medium sized enterprises. We associate this dispersion with the loan officers' use of "Discretion" in the loan rate setting process. We find that "Discretion" is most important if: loans are small and unsecured; firms are small and opaque; the firm operates in a large and highly concentrated banking market; and the firm is distantly located from the lender. Consistent with the proliferation of information-technologies in the banking industry, we find a decreasing role for "Discretion" over time in the provision of small credits to opaque firms. While widely used in the pricing of loans, "Discretion" plays only a minor role in the decisions to grant loans.

(Osei-Assibey \& Asenso, 2015) states the fact that this paper ambitions to investigate the impact of the important financial institution's regulatory capital on industrial banks specific performance results together with credit score supply, hobby fee spread and non-performing loans. The observe finds advantageous courting among an internet minimum capital ratio and the net hobby margin. The have a look at similarly finds proof to help the reality that excessive minimum capital requirement and excess capital above the minimal required power credit score boom in the banking quarter of Ghana. High excess capital will increase threat-taking activities of the banks, as extra capital is located to be associated with high NPL ratios. Given the financial benefits and expenses of sharply increasing bank regulatory capital, our effects communicate to the continuing debates on the proper stage of capital, the effectiveness of the financial institution of Ghana coverage fee and the high lending fees that appear to respond simplest slowly to macroeconomic indicators such as the PR and the inflation charge. The empirical literature has now not paid enough attention to the impact of regulatory capital at the 3 precise financial institution-degree effects - NPLs, interest rate unfold and the nature of interrelationships amongst these variables, mainly within the African context.

(Sensarma \& Jayadev, 2009) states the fact that the paper translates the selected accounting ratios as risk control variables and attempts to gauge the general danger control capability of banks via summarizing those accounting ratios as rankings via the software of multivariate statistical strategies. The outcomes based totally on information for Indian banks screen that banks' hazard control talents had been enhancing over time besides for inside the remaining years. Returns on the banks' shares look like touchy to hazard control functionality of banks. The outcomes advise that banks that want to beautify shareholder wealth must focus on efficiently coping with numerous underlying dangers. The findings have implications for traders who may additionally advantage by way of going long on shares of banks that are better chance managers. $2^{\text {nd }}$, the study develops summary rankings of hazard 
control competencies of banks. $3^{\text {rd }}$, chance control is shown to be a critical determinant of inventory returns of banks.

(Vishwakarma, 2015) states the fact that this paper ambitions to examine the threat premium for traders in a changing records surroundings inside the Taiwan, the big apple and London actual property markets from March 2006 to November 2014. Empirical proof indicates that the time-varying risk top rate modified for the Taiwan actual estate market with a new facts set. No such evidence changed into discovered for the big apple and London real estate markets. Using the index of preferred and bad Taiwan actual estate funding Trusts to take a look at the Taiwan real estate enterprise might also have aggregation outcomes in result. The present look at will offer guidance to investors in addition to policymakers regarding the Taiwan real estate market.

\section{RESEARCH FRAMEWORK}

This article is written on the impact of risk premium and its effect on non-performing bank loans; this tell us that what's a relationship between these different variables. We consider that there will be a change in Non-performing bank loans due to change in Risk premium.

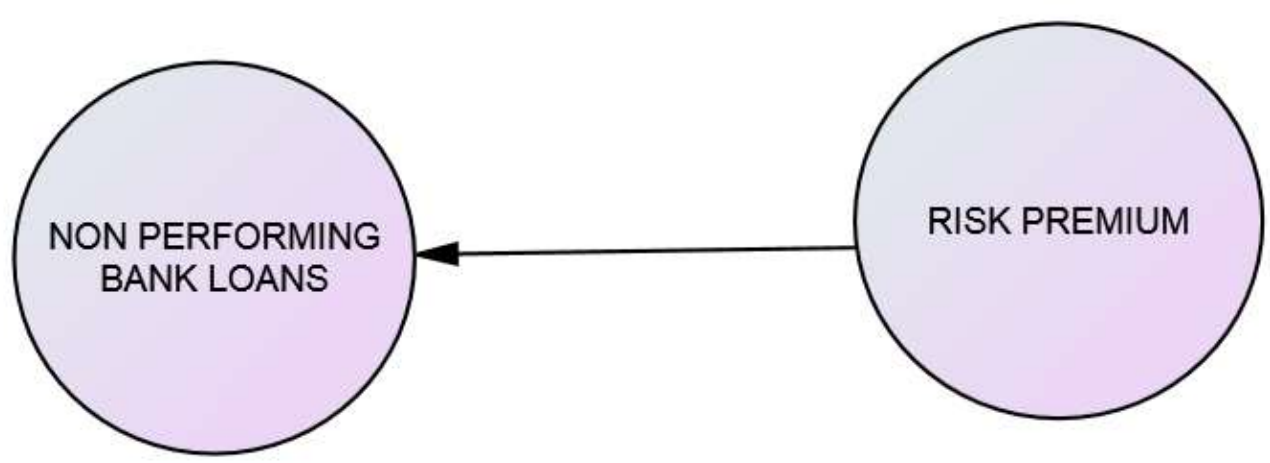

Figure: 1 Risk Premium Model

\section{Research methodology}

The Source for the data collected that we have used for the selected set of different variables have been gathered from the published annual reports and the official websites of the banks. The time period that have been selected for this research study is from the year of 1998 to 2010

\section{Hypothesis:}

HO: There is no significant impact on Risk premium through banks non-performing loans $\mathrm{H} 1$ : There is significant impact on Risk premium through banks non-performing loans.

\section{Econometric Model}

For the present research analysis selection of the different tools, variables for banking non-performing loans as the dependent variable and independent variables have been selected. For the understanding of the regression equation in an easy and simple way the pooled data from the period of 1998 to 2010 of 8 western countries have been selected. The data is very flexible having different slope coefficients and parameters and is very unrestricted for each period of study. The time series period observed our cross sectional entities are as under:

$$
\text { Yit }=\beta 1 \text { it }+\beta 2 i t \times 2 i t+\beta 3 i t x 3 i t+\ldots \ldots . . B \text { Nit } x N i t+e t
$$

Dependent variable in the analysis is donated by Yit which is return on equity over a period of time $t$, and the terms intercept terms $\beta 1$ it $\beta 2 i t \beta 3 i t \beta N$ it are the coefficient and $x 2 i t, x 3 i t$, $x$ Nit independent variables indicator. 


\section{EMPIRICAL RESUTLS AND DISCUSSIONS}

Table 1: Descriptive Statistics

\begin{tabular}{|l|l|l|l|}
\hline Variables---------------Non-performing loan & Variables----------------Risk premium \\
\hline Mean & 4.07 & Mean & 2.70 \\
\hline Standard Error & 0.39 & Standard Error & 0.18 \\
\hline Median & 2.60 & Median & 2.35 \\
\hline Mode & 2.60 & Mode & 1.80 \\
\hline Standard Deviation & 4.02 & Standard Deviation & 1.91 \\
\hline Range & 26.3 & Range & 8.60 \\
\hline Minimum & 0.40 & Minimum & 0 \\
\hline Maximum & 26.7 & Maximum & 8.60 \\
\hline Count & 104.0 & Count & 104.0 \\
\hline
\end{tabular}

In the above table are the results of descriptive statistics of the study. From the Table we can check that the maximum mean value is 4.072115385 which is off non -performing loan and minimum mean value is 2.706730769 of Risk premium. Majority of variables have minimum value of 0 whereas the maximum value for all variables differs. The second row shows the Standard error of all variables. Mode of non -performing loan is 2.6and risk premium .is 1.8. The value of Standard deviation is also mention above. $6^{\text {th }}$ row shows the range of all the variables and in the last row the count show the total number of observations of all variables.

Table 2: Correlation Matrix

\begin{tabular}{|l|l|l|}
\hline & Non-performing loans & Risk Premium \\
\hline Non- performing loans & 1 & \\
\hline Risk Premium & 0.51 & 1 \\
\hline
\end{tabular}

Before starting the further research analysis it is necessary to check, what is the correlation level between the variables that has been selected the multi co linearity problem. In the table above are the results showing the correlation between all the selected variables selected for this research analysis. From the above results we can check that there is no high level of correlation between all the variables used in this analysis.

Table 3: Regression Summary/Results

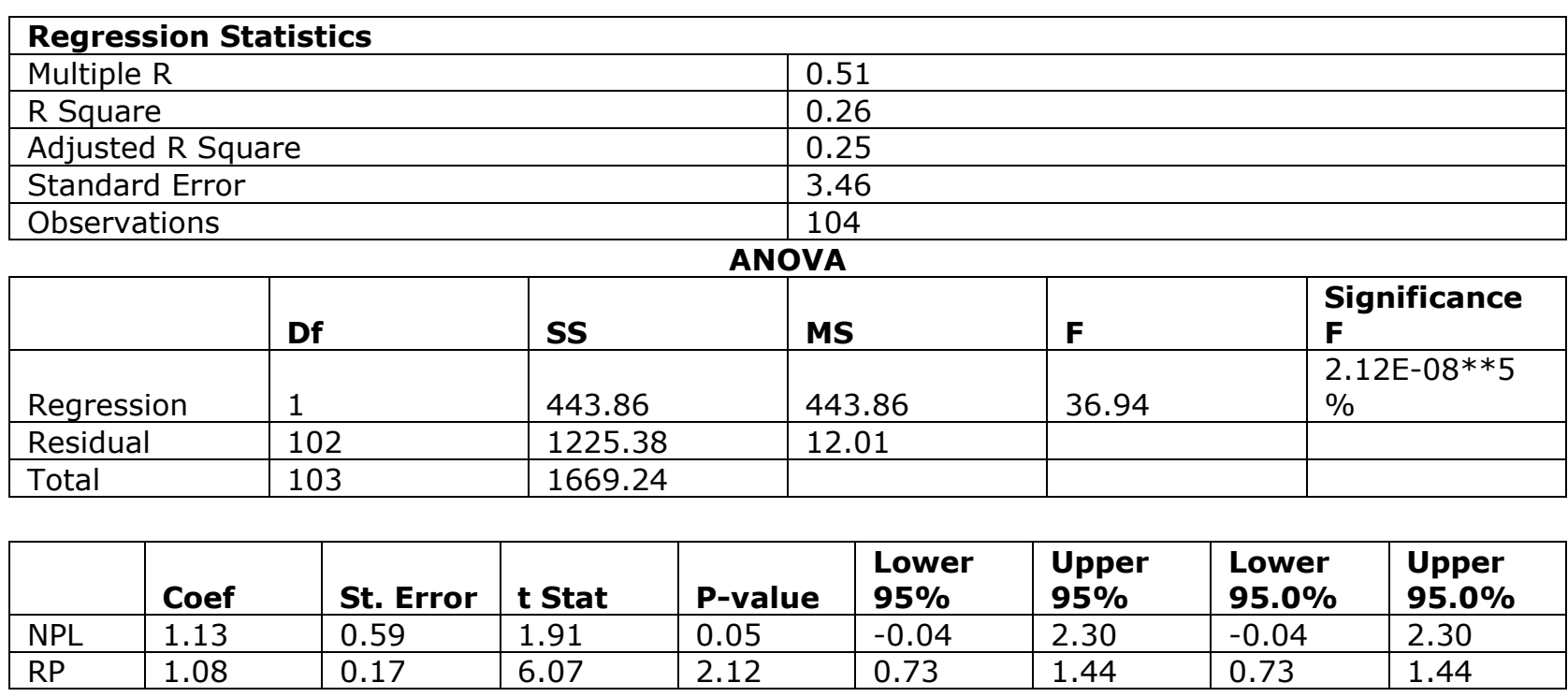


In the above table are the different results of panel data analysis for the dependent variable which risk premium of the currently non-performing banks loans in Pakistan. The results shows that among all the models, the coefficient value of risk premium and non-performing bank loans are significant at $0,1 \%$. These results are showing that all these variables have a significant impact on financial performance of the banks over a period of time.

Table 4: Fixed or Random: Housman test Results (Coefficient)

\begin{tabular}{|l|l|l|l|l|}
\hline & (b) Fixed & (B) Random & (b-B) Difference & $\begin{array}{l}\text { SQRT (diag (V_b-V_B) } \\
\text { S.E }\end{array}$ \\
\hline Risk premium & 4.16 & 2.32 & 1.84 & 0.29 \\
\hline
\end{tabular}

$\mathrm{b}=$ consistent under $\mathrm{Ho}$ and $\mathrm{Ha}$; obtained from xtreg

$B=$ inconsistent under $\mathrm{Ha}$, efficient under $\mathrm{Ho}$; obtained from xtreg

Test: Ho: difference in coefficients not systematic

Chi2 $(1)=(b-B)^{\prime}\left[\left(V_{-} b-V_{-} B\right)^{\wedge}(-1)\right](b-B)$

$=40.42$

Prob $>$ chi2 $=0.0000$

(V_b-V_B is not positive definite)

Housman test results for fixed or random effect model shows that the value 0.0000 is less than 0.05 which concludes that we should use the Fixed Effect Model (FEM) meaning that in the model we will control the effects on variables.

\section{CONCLUSION}

From the above results, we can clearly see that discussing the determinants of Non-performing bank loans is not an independent decision. There are a number of other factors that can affect it. The major factors that can effect or have significance impact are Risk premium. Therefore, whenever the banking experts want to make decisions relating to Non-performing bank loans they must consider the above mentioned factors which tells the determinants for the banking sector in both developing and developed country. As we all know that as people are becoming more knowledgeable about growing trends the use of banking facilities usage are increasing day by day. Bank is becoming more and more active in almost every field of life such as business people are using more and more banks activates to do their business transactions through the use of backing services, bank also planning a very important role in giving loan to public. People are browning more different types of loans from banks for example car loan, house loan, loan for business and so on. By these growing trends of banking we can see that how much important it is for the management team of the banking firm to make good strategies, proper planning and decision making regarding to the finance performance of the bank.

The banking firm finance performance can be measure by using a verity of tools, methods such as non-performing loans, return on assets, net profit, income, lending, return on investments, investments, earning per share, and many more for this project we selected return on equity. Just as dependent variable there are a number of independent factors are also available. To check the finance performance, we select its proxy then we also select proxies for independent variable as well, then we check does the independent variable have significance impact on the dependent variable (nonperforming bank loans) or not.

There are number to method available to check it such as fixed effect model, random effect model, least square dummy variable model, pooled regressing model. In this research model study we found out that many factors such as total assets, income before tax and investment had significance impact on the proxy of finance performance which we selected was non-performing bank loans. Firms that do good job in driving profits from their operations typically have competitive advantage it's a feature that normally translates into superior returns for investors. The relationship between the companies profit and the investors return makes non-performing bank loans a particularly valuable tool to examine. 
Hafiz Waqas Karman, Shameer Malik, Hamas Butt, M. Hamza, Umair Afzal, Shahzaib Maqbool Risk Premium and Its Effect on Bank's Non-Performing Loans

\section{REFERENCES}

- Barseghyan, L. (2010). Non-performing loans, prospective bailouts, and Japan's slowdown. Journal of Monetary Economics, 57(7), 873-890, CrossRef

- Bushman, R. M., \& Williams, C. D. (2012). Accounting discretion, loan loss provisioning, and discipline of banks' risk-taking. Journal of Accounting and Economics, 54(1), 1-18, CrossRef

- Cerqueiro, G., Degryse, H., \& Ongena, S. (2011). Rules versus discretion in loan rate setting. Journal of Financial Intermediation, 20(4), 503-529.

- Chateau, J.-P., \& Wu, J. (2007). Basel-2 capital adequacy: Computing the 'fair'capital charge for loan commitment 'true'credit risk. International Review of Financial Analysis, 16(1), 1-21, CrossRef

- Cook, D. O., Schellhorn, C. D., \& Spellman, L. J. (2003). Lender certification premiums. Journal of Banking \& Finance, 27(8), 1561-1579, CrossRef

- Dietsch, M., \& Petey, J. (2015). The credit-risk implications of home ownership promotion: The effects of public subsidies and adjustable-rate loans. Journal of Housing Economics, 28, 103120, CrossRef

- Hassan, M. K., \& Sackley, W. H. (1994). A Methodological investigation of risk exposure of bank off-balance sheet loan commitment activities. The Quarterly Review of Economics and Finance, 34(3), 283-299, CrossRef

- Ioannidou, V. P., \& Penas, M. F. (2010). Deposit insurance and bank risk-taking: Evidence from internal loan ratings. Journal of Financial Intermediation, 19(1), 95-115, CrossRef

- Lehar, A. (2005). Measuring systemic risk: A risk management approach. Journal of Banking \& Finance, 29(10), 2577-2603, CrossRef

- Osei-Assibey, E., \& Asenso, J. K. (2015). Regulatory capital and its effect on credit growth, non-performing loans and bank efficiency: Evidence from Ghana. Journal of Financial Economic Policy, 7(4), 401-420, CrossRef

- Sensarma, R., \& Jayadev, M. (2009). Are bank stocks sensitive to risk management? The journal of risk finance, $10(1), 7-22$, CrossRef

- Stanhouse, B., \& Stock, D. (2004). The impact of loan prepayment risk and deposit withdrawal risk on the optimal intermediation margin. Journal of Banking \& Finance, 28(8), 1825-1843, CrossRef

- Vishwakarma, V. K. (2015). The dynamics of risk premium: the case of the Taiwan real estate market. The journal of risk finance, 16(4), 463-482, CrossRef 
Hafiz. Waqas Karman, Shameer Malik, Hamas Butt, M. Hamza, Umair Afzal, Shahzaib Maqbool Risk Premium and Its Effect on Bank's Non-Performing Loans

\section{APPENDIX}

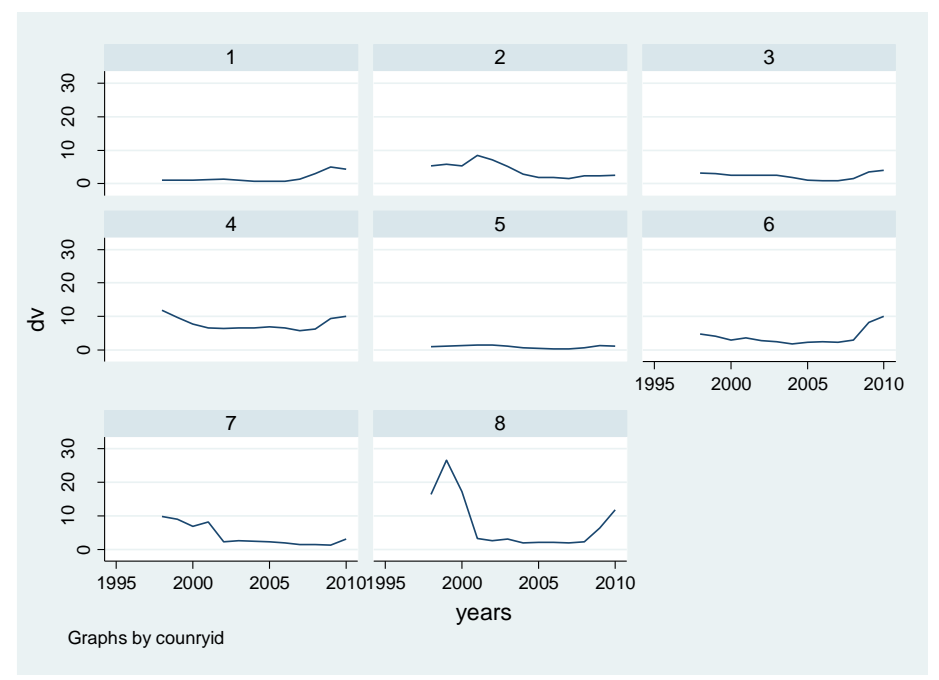

Graph 1: Non-performing bank loans trend separately

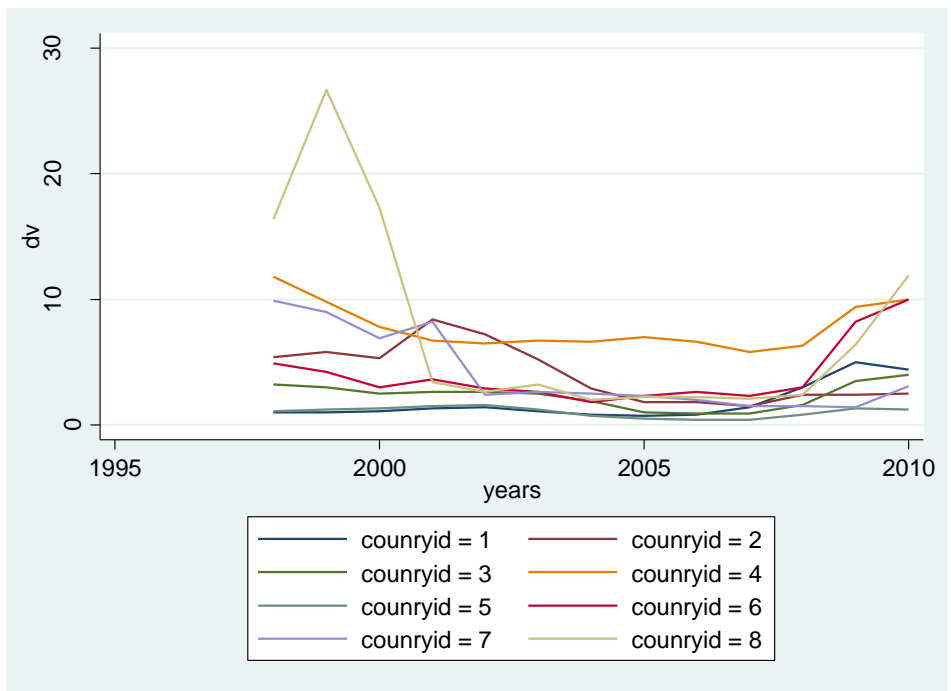

Graph 2: Non-performing bank loans trend togather 
Hafiz Waqas Karman, Shameer Malik, Hamas Butt, M. Hamza, Umair Afzal, Shahzaib Maqbool Risk Premium and Its Effect on Bank's Non-Performing Loans

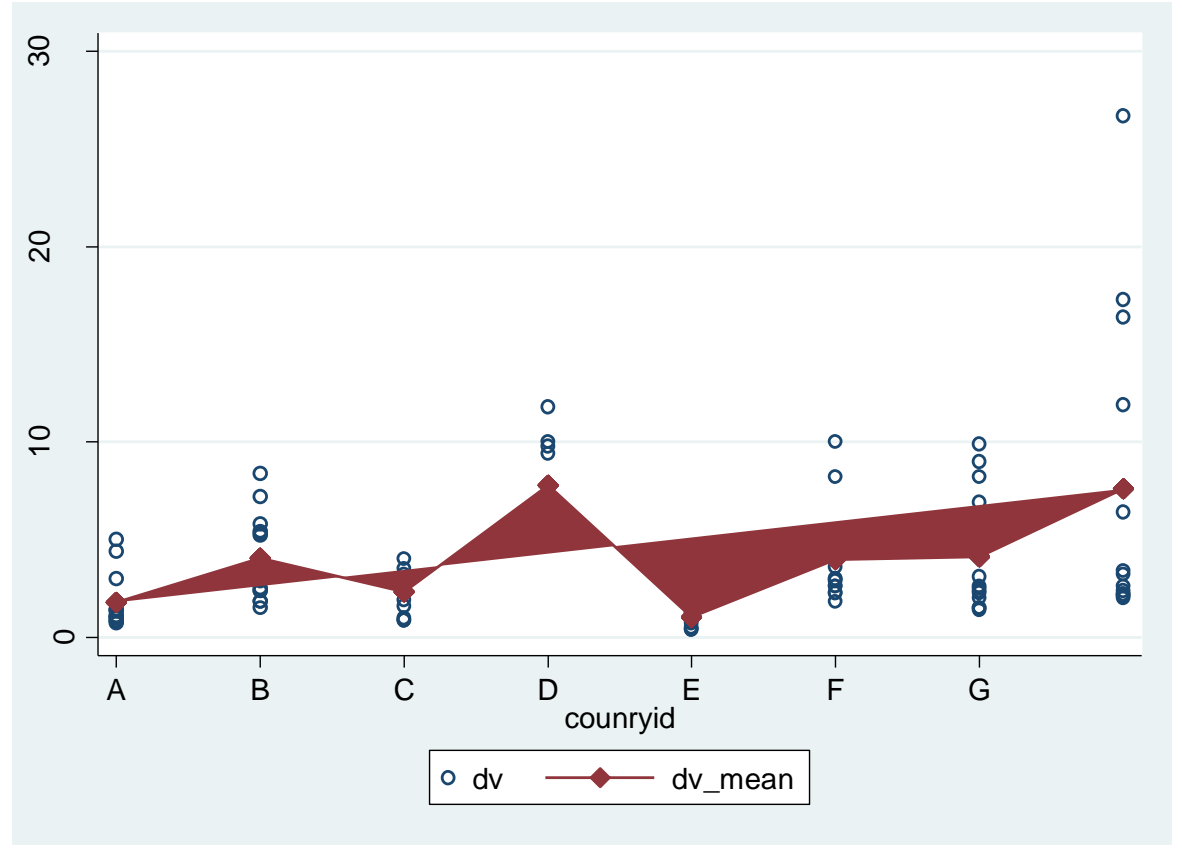

Graph 3: Fixed effects: heterogeneity across entities

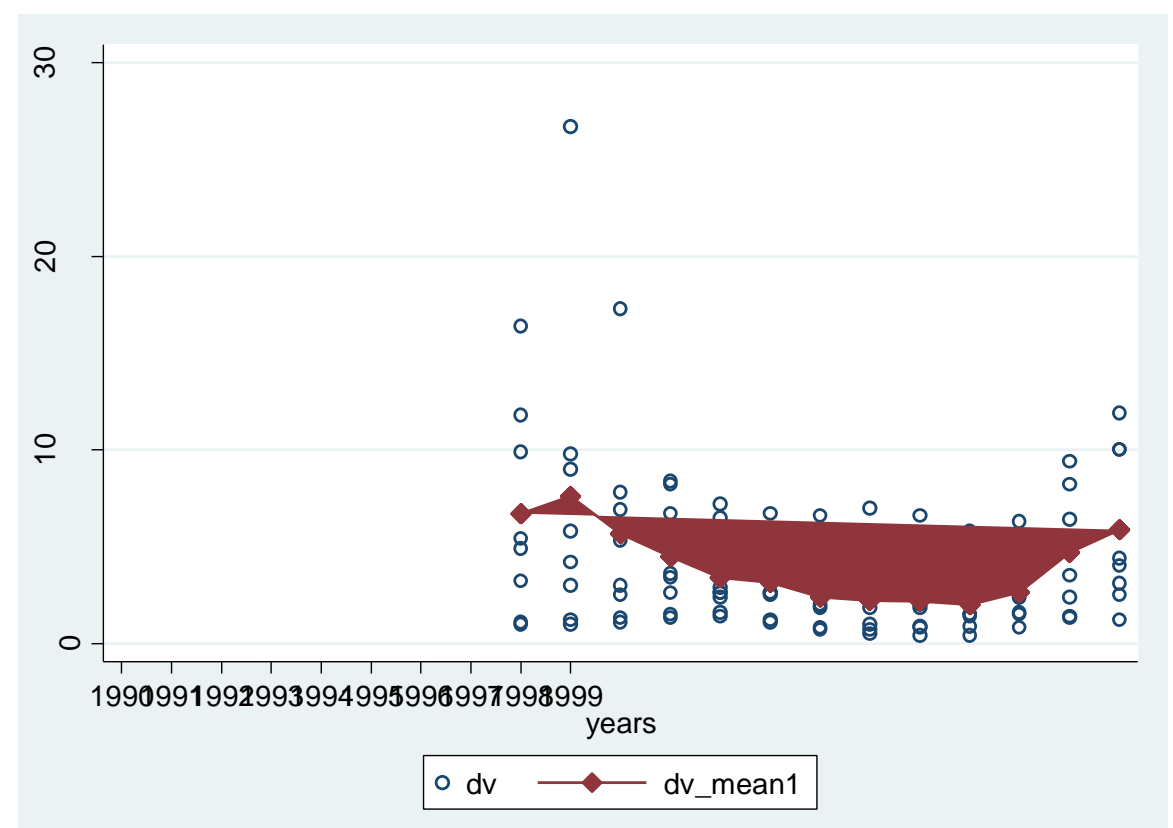

Graph 4: Fixed effects: Heterogeneity across years 
Hafiz. Waqas Karman, Shameer Malik, Hamas Butt, M. Hamza, Umair Afzal, Shahzaib Maqbool Risk Premium and Its Effect on Bank's Non-Performing Loans

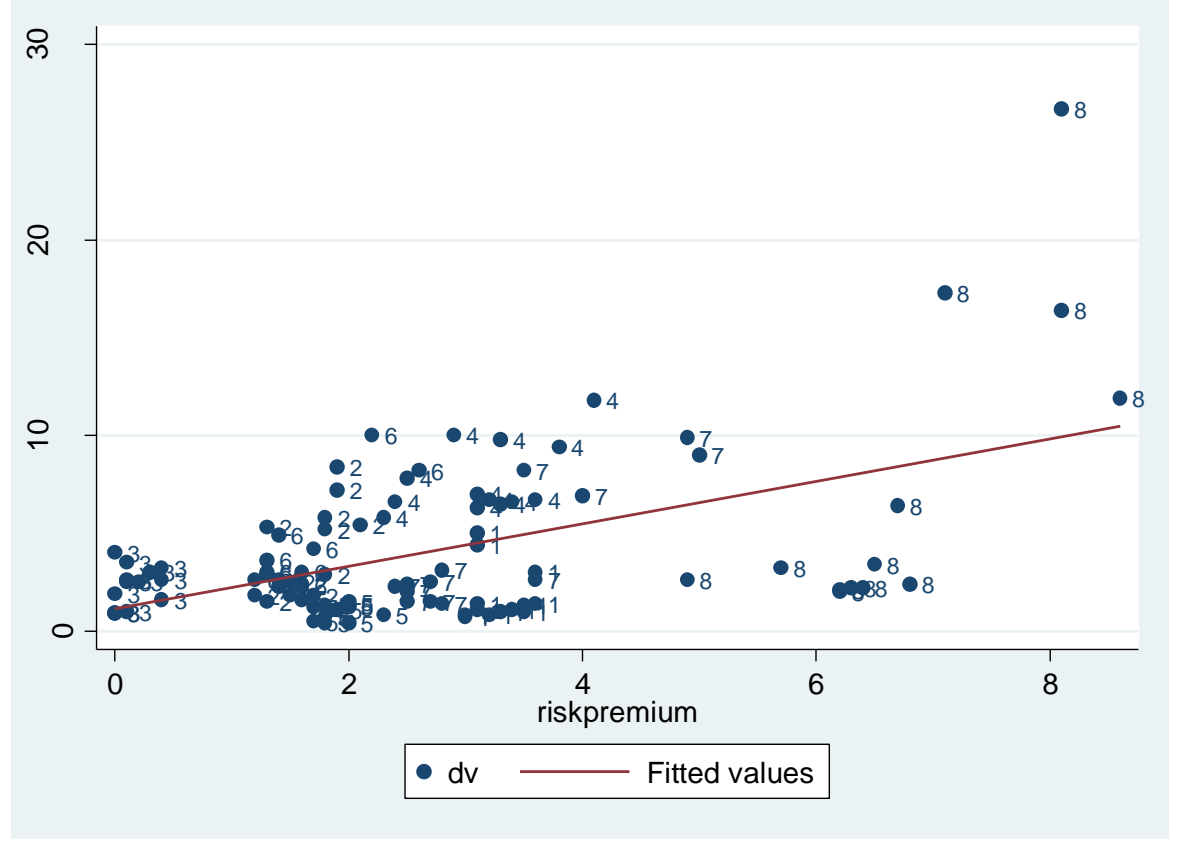

Graph 5: Non-performing loans scatter with risk premium 